Jurnal PG-PAUD Trunojoyo : Jurnal Pendidikan dan Pembelajaran Anak Usia Dini, Volume 7, Nomor 2, Oktober 2020 hal 23-32, ISSN : 2528-3553 (online), ISSN: 2407-4454 (print)

\title{
ANALISIS AKTIVITAS PENDIDIKAN DI TK LABORATORIUM AICHI JEPANG BERDASARKAN PRINSIP-PRINSIP NEUROSAINS
}

\author{
Hifizah Nur \\ Psikologi, Universitas Mercu Buana Jakarta \\ email: hifizah.nur@mercubuana.ac.id \\ Received (Juni), Accepted (September), Published (Oktober)
}

\begin{abstract}
Analysis of Educational Activities in Aichi Japanese Laboratory Kindergartens Based on Neuroscience Principles. This research goals are to see how the free play method is done in Japanese kindergarten and whether the activities in Japanese kindergarten are in accordance with the principles of neuroscience. The research was conducted using naturalistic observational qualitative method. Researcher observed the activities of 5-6 years old students at the Aichi University of Education's laboratory of kindergarten for one day, from 09.00 to 14.00 JST. The results of the study showed that the activities in the kindergarten were very suitable to the 8 principles of neuroscience.
\end{abstract}

Keywords: free play, Japanese kindergarten, principles of neuroscience, naturalistic observation.

Abstrak: Analisis Aktivitas Pendidikan di TK Laboratorium Aichi Jepang Berdasarkan PrinsipPrinsip Neurosains. Penelitian ini bertujuan untuk melihat bagaimana metode bermain bebas yang dilakukan di TK jepang. Selain itu penelitian ini juga untuk melihat apakah aktivitas pendidikan di TK Jepang sesuai dengan prinsip-prinsip neurosains. Penelitian dilakukan dengan menggunakan metode observasi kualitatif yang bersifat naturalistik. Peneliti mengobservasi aktivitas siswa-siswa kelas TK B di TK laboraturium Aichi University of Education selama satu hari, dari jam 09.00 sampai jam 14.00 JST. Hasil penelitian menunjukkan bahwa aktivitas di TK tersebut sangat seusai dengan 8 prinsip neurosains.

Kata kunci: bermain bebas, TK Jepang, prinsip-prinsip neurosains, observasi naturalistik. 
Jurnal PG-PAUD Trunojoyo : Jurnal Pendidikan dan Pembelajaran Anak Usia Dini, Volume 7, Nomor 2, Oktober 2020 hal 23-32, ISSN : 2528-3553 (online), ISSN: 2407-4454 (print)

\section{PENDAHULUAN}

Mana yang lebih baik untuk dijadikan kurikulum di Taman Kanak-kanak, apakah bermain bebas atau bermain pedagogis? Perdebatan dengan topik ini sering kali muncul di ranah pendidikan anak usia dini (Cutter-Mackenzie \& Edwards dalam Hunter, et al., 2017). Bermain pedagogis terdiri dari berbagai macam bentuk aktivitas edukatif yang memiliki tujuan tertentu, yang menawarkan kesempatan yang berharga agar anak bisa mengembangkan kesadaran dan pemahaman terhadap dunia di sekitarnya (Woods, CutterMackenzie \& Edwards dalam Hunter et al., 2017). Sedangkan bermain bebas membutuhkan kesimbangan pedagogis yang halus antara pengetahuan, nilai-nilai, dan tindakan dalam pengalaman pendidikan lingkungan dalam pendidikan anak usia dini (Tranter \& Malone dalam Hunter et al., 2017). Keterlibatan guru dalam permainan anak-anak juga sesuatu yang sangat penting dalam proses belajar.

Pendidikan anak usia dini di Indonesia lebih banyak yang menggunakan pola permainan pedagogis dalam aktivitas sehariharinya. Dalam banyak penelitian tentang aktvitas pendidikan anak usia dini di Indonesia, bisa ditemukan banyak sekali aktivitas yang merupakan bentuk bermain pedagogis, namun bermain bebas sebagai kegiatan inti dalam aktivitas di TK belum banyak ditemukan di Indonesia.

Pendidikan Anak Usia Dini di Indonesia adalah suatu upaya pembinaan yang ditujukan kepada anak sejak lahir sampai dengan usia enam tahun yang dilakukan melalui pemberian rangsangan pendidikan untuk membantu pertumbuhan dan perkembangan jasmani dan rohani agar anak memiliki kesiapan dalam memasuki pendidikan lebih lanjut (Istiana, 2014). Sedangkan tujuan khusus pendidikan anak usia dini di Indonesia adalah: 1. Agar anak percaya akan adanya Tuhan dan mampu beribadah serta mencintai sesamanya. 2. Agar anak mampu mengelola ketrampilan tubuhnya termasuk gerakan motorik kasar dan motorik halus, serta mampu menerima rangsangan sensorik. 3. Anak mampu menggunakan bahasa untuk pemahaman bahasa pasif dan dapat berkomunikasi secara efektif sehingga dapat bermanfaat untuk berpikir dan belajar. 4 . Anak mampu berpikir logis, kritis, memberikan alasan, memecahkan masalah dan menemukan hubungan sebab akibat. 5. Anak mampu mengenal lingkungan alam, lingkungan sosial, peranan masyarakat dan menghargai keragaman sosial dan budaya serta mampu mengembangkan konsep diri yang positif dan control diri. 6. Anak memiliki kepekaan terhadap irama, nada, berbagai bunyi, serta menghargai kreatif.

Tidak ada aturan khusus yang mengharuskan TK di Indonesia untuk melaksanakan permainan pedagogis dalam metode pembelajaran, sehingga sebenarnya metode bermain bebas juga bisa digunakan untuk mencapai tujuan pembelajaran.

Jepang merupakan salah satu negara yang menjadikan aktivitas bermain bebas sebagai aktivitas utama di Taman Kanak-kanak. Achmadi dan Shobahiya (2008) dalam penelitiannya tentang perbedaan antara system pendidikan TK di Indonesia dengan Jepang mengungkapkan sebagai berikut;

"Kurikulum TK di Jepang tidak membebani anak, karena anak tidak dijejali materi-materi pelajaran secara kognitif tetapi lebih pada pengenalan dan latihan ketrampilan hidup yang dibutuhkan anak untuk kehidupan seharihari, seperti latihan buang air besar sendiri, gosok gigi, makan, dan lain sebagainya. Sedangkan kurikulum di Indonesia telah berorientasi pada pengembangan intelektual anak."

Bermain bebas dalam TK di Jepang berfungsi sebagai sarana untuk mengaktifkan kemampuan berfikir anak, sebagai sarana untuk menyalurkan apa yang mereka pikirkan 
Jurnal PG-PAUD Trunojoyo : Jurnal Pendidikan dan Pembelajaran Anak Usia Dini, Volume 7, Nomor 2, Oktober 2020 hal 23-32, ISSN : 2528-3553 (online), ISSN: 2407-4454 (print)

melalui permainan yang kreatif, dan juga menunjang kesehatan fisik anak saat bermain bebas di halaman sekolah.

Dalam neurosains, enam tahun pertama adalah masa-masa yang paling cepat dalam perkembangan otak dalam kehidupan manusia. Saat baru lahir, bayi memiliki 100 miliar neuron yang terus membentuk sambungansambungan sinaps melalui rangsangan sensori dan motoriknya. Sambungan itu terus terbentuk melalui pengalaman yang dilalui oleh anak. Namun, prinsip yang dipakai dalam perkembangan otak adalah bila tidak digunakan, maka neuron akan mati atau dipangkas. Otak anak akan berkembang dengan baik bila ada pengalaman yang diulang. Hubungan sinaps akan semakin kuat dan semakin baik bila sering digunakan. Hubungan sinaps juga akan baik bila anakanak punya kesempatan untuk meningkatkan kemampuan otot halus dan kasarnya, anak memiliki kesempatan untuk mempraktekan kemampuan sosialnya dan berinteraksi secara langsung dengan lingkungan. Dengan alasan inilah maka bermain menjadi unsur yang penting pada anak usia dini.

Penelitian ini bertujuan untuk memaparkan aktivitas bermain bebas yang dilakukan di TK Jepang, sehingga bisa menjadi salah satu contoh bagi praktisi pendidikan TK di Indonesia dalam melaksanakan aktivitas TK di tempatnya mengajar. Selain itu, tujuan dari penelitian ini adalah untuk menganalisa apakah aktivitas di TK Jepang sesuai dengan konsep-konsep pendidikan anak usia dini berdasarkan neurosains.

Metode yang digunakan dalam penelitian ini adalah metode kualitatif dengan observasi naturalistic, yang dilakukan dari jam 09.0014.00 JST di TK Aichi University of Education.

\section{METODE PENELITIAN}

Penelitian ini menggunakan studi literatur yang mencari prinsip-prinsip neurosains yang penting untuk diimplementasikan dalam dunia pendidikan. Selain itu peneliti juga menggunakan metode kualitatif dengan teknik utama melakukan observasi aktivitas di TK laboraturium Aichi University of Education di Jepang. Observasi dilakukan satu hari selama jam pembelajaran, dari pukul 09.10-14.00 JST. Fokus observasi yaitu pada siswa kelas TK Besar (usia 5-6 tahun) dengan aktivitas pembelajaran di luar dan di dalam kelas.

Penelitian dilakukan dalam beberapa tahap. Tahap pertama, peneliti merumuskan prinsip-prinsip neurosains yang sesuai dengan hasil-hasil penelitian selama ini. Tahap kedua, peneliti melakukan observasi di TK laboraturium Aichi University of Education. Terakhir, peneliti menganalisa kurikulum dan hasil observasi di TK Jepang dengan berdasarkan prinsip-prinsip neurosains.

\section{HASIL DAN PEMBAHASAN}

\section{a. Prinsip-prinsip Pendidikan TK berdasarkan neurosains}

Dari studi literature tentang prinsip-prinsip neurosains ada beberapa prinsip yang sangat penting untuk pendidikan di taman kanakkanan, yaitu;

1. Pertumbuhan otak yang cepat pada anak usia di bawah 6 tahun, mendorong mereka untuk mengeksplorasi, menemukan, bermain, dan membuat hubungan alami antara diri, orang lain, dan dunia sekitarnya.

2. Kondisi yang menyenangkan, aman, dan nyaman akan mengaktifkan bagian cerebral korteks (neokorteks) sehingga dapat mengoptimalkan proses belajar dan meningkatkan kepercayaan diri anak.

3. Di usia 3-6 tahun merupakan masa di mana prefrontal korteks berkembang dengan sangat pesat. Prefrontal 
Jurnal PG-PAUD Trunojoyo : Jurnal Pendidikan dan Pembelajaran Anak Usia Dini, Volume 7, Nomor 2, Oktober 2020 hal 23-32, ISSN : 2528-3553 (online), ISSN: 2407-4454 (print)

korteks ini memiliki fungsi eksekutif, sehingga latihan-latihan pemusatan perhatian, mengontrol tindakan seperti melawan kebiasaan, godaan atau gangguan, mengingat informasi dan membuat perencanaan menjadi aktivitas yang penting untuk dilakukan.

4. Proses pembelajaran dilakukan dengan cara yang menyenangkan agar otak siswa memproduksi neurotransmitter dopamine yang membuat siswa menyukai aktivitas di TK dan terlibat aktif dalam proses pembelajaran.

5. Aktivitas belajar ditargetkan sampai pada keterampilan, sehingga bisa dicapai oleh semua siswa.

6. Setiap hari tugas guru adalah menyapa dengan sambutan hangat, mendorong mereka untuk berkembang sebagai individu, memberikan tantangan pribadi, melibatkan mereka dalam pengembangan lingkungan kelas, dan mendukung perbedaan individu

7. Otak anak-anak perlu dihadapkan dalam kehidupan nyata, langsung, dan pengalaman belajar yang bermakna, yang terkait dengan kesamaan dan dihadapkan pada beberapa bentuk pemecahan masalah.

8. pembelajaran anak usia dini menggunakan esensi bermain.

\section{b. Hasil Observasi aktivitas di TK Laboraturium Aichi Jepang}

Pada pukul 09.00-11.20 JST anak-anak melakukan permainan bebas, artinya setiap anak bebas memilih jenis permainan apa yang ingin dilakukan dan dengan siapa ia ingin melakukan permainan tersebut. Peneliti melakukan observasi pada enam macam permainan. Permainan tersebut adalah pesta di bak pasir, dodgeball (melempar bola mengenai tubuh lawan), lompat tali, bermain pelayan kafe, latihan sepeda roda satu, dan berputar di tiang gymnastic (pull up bar). Permainan di dalam ruangan yang diobservasi adalah permainan toko kue saja, namun di tempat lain, anak-anak ada yang ikut bermain permainan rumah hantu. Berikut ini hasil observasi dari permainan yang dilakukan mereka;

\section{Pesta Bak Pasir}

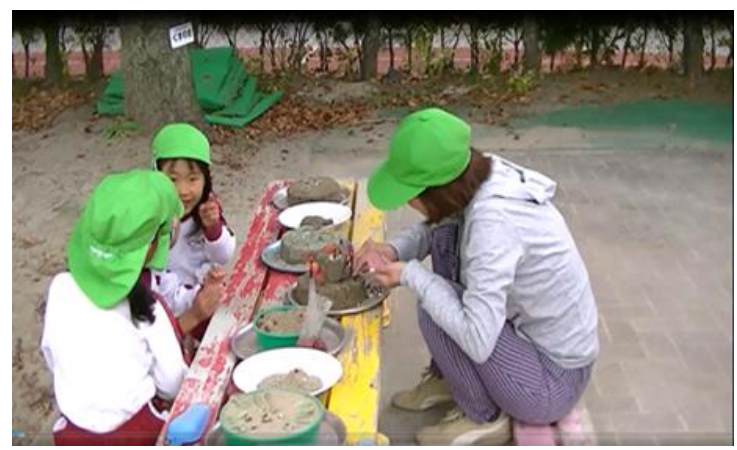

Gambar 1. Pesta Bak Pasir

Di samping bak pasir wali kelas dari kelas Putih (TK B), sedang menghias cake yang berasal dari pasir dengan biji-bijian dan dedaunan. Di sana terlihat anak-anak yang memperhatikan apa yang dilakukan oleh guru tersebut. Setelah memperhatikan, mereka juga ikut membuat cake dari pasir. Setelah selesai membuat cake, anak itu ingin meletakkannya diatas meja di sampingnya, tapi karena hampir jatuh, temannya membantu membawakan cake tersebut. Anak itu ingin menghias kuenya seperti yang dilakukan bu guru. Ia menggunakan biji-bijian dan dedaunan untuk menghias kuenya. Mereka memanggil anak-anak TK tengah, dan menyuruh mereka makan cake. Ketika anakanak TK tengah akan memakan cakenya, anak TK besar berkata "Jangan diberantakin betulan ya!". Saat mereka bosan dengan permainan tersebut,anak TK besar meninggalkan tempat itu dan mengejar anak kelas Putih. Mereka mengajak temantemannya untuk kembali ketempat cake tadi. 


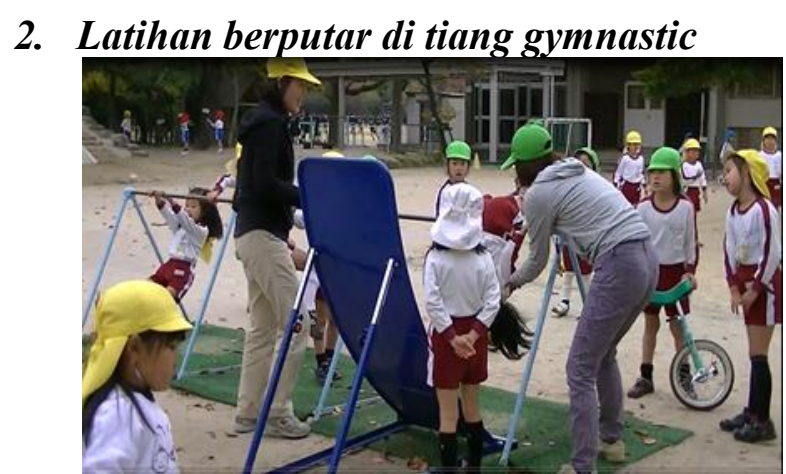

Gambar 2. Berputar di Tiang

Gymnastic

Di area tiang gymnastik terlihat wali kelas dari kelas Putih dan kelas Biru sedang membantu seorang anak yang sedang berlatih berputar di tiang gimnastik. Mereka berusaha menjelaskan caranya agar bisa berputar dengan baik. Ada anak lain yang menyemangatinya, sedangkan anak lain lagi yang sudah bisa berusaha menunjukkan caranya. Anak yang sedang berlatih itu berkali-kali menunjukkan usaha kerasnya agar bisa berputar di tiang gimnastik. Akhirnya anak itu berhasil berputar. Bu Guru dan anak lain yang melihatnya langsung bertepuk tangan. Bu Guru berkata, "Tenagamu jadi lebih kuat ya, coba kamu latihan lagi." Anak itu mencoba berputar sekali lagi, dan bisa bisa melakukannya dengan baik. Bu Guru kembali bertepuk tangan. "Hebat! Waktunya lebih cepat dari sebelumnya. Hebat!!" Katanya, memuji anak tersebut.

\section{Bermain Dodgeball (Lempar bola)}

Permainan dodgeball adalah permainan di mana pemain dari kedua tim mencoba untuk melempar bola untuk mengenai tubuh lawan dan berusaha menghindar dari lemparan pihak lawan. Tujuan dari permainan ini adalah untuk mengurangi jumlah lawan dengan membuat mereka terkena bola atau keluar dari area pertandingan (Wikipedia).

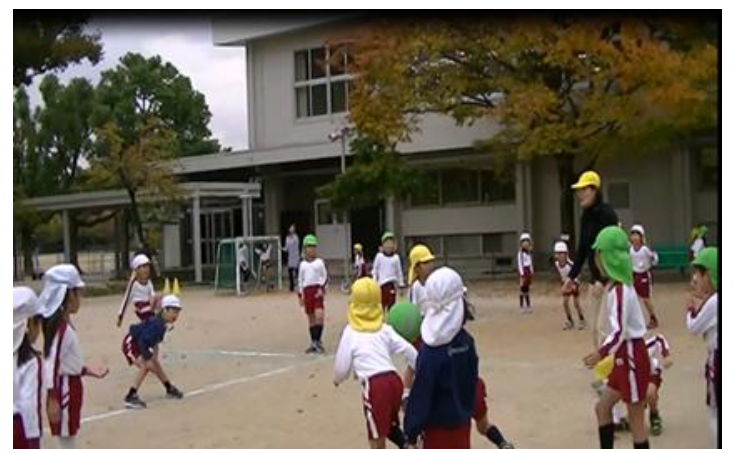

Gambar 3. Lempar Bola

Jam 9.10 JST, anak-anak be rmain dodge ball. Pada saat itu anak kelas putih TK besar bermain bersama dengan kelas biru, kelas TK besar lainnya. Masing-masing kelas berusaha untuk mengalahkan kelas lainnya. 2 menit setelah itu, wali kelas dari kelas Biru ikut serta dalam permainan. Permainan semakin memanas. Ada anak laki-laki yang bisa menangkap bola yang dilempar dari kelompok lawan dengan baik. Anak lainnya melemparkan bola dengan kuat ke arah guru, tapi bu guru berhasil menangkap bola. Bola dilempar oleh guru menuju anggota grup lawan. Lalu grup itu mengembalikan bola, dan dengan bantuan anggota kelompok yang sama di luar lapangan, bola di lempar dan mengenai salah satu anggota grup Biru. Anak yang terkena bola mematuhi peraturan dan keluar dari permainan. Anak-anak memutuskan dengan jyanken atau hompimpa ala jepang, siapa yang akan memukul selanjutnya.

\section{Bermain Pelayan Kafe}

Anak-anak dan Bu Guru sedang menyiapkan kafe bersama-sama. Kelas di setting menyerupai kafe. Di tengah kelas, terdapat dua meja yang sudah diatur untuk tamu. Di atasnya diletakkan bunga dan daftar menu. Di sekelilingnya terdapat kursi yang berjajar untuk tamu. Di sebelahnya ada kasir, lalu di atas meja di sebelahnya lagi ada es krim dan berbagai jenis cake yang kelihatannya enak sekali. Di tempat yang agak jauh, ada meja yang khusus disediakan untuk membuat cake. Anak-anak membagikan peran di antara 
Jurnal PG-PAUD Trunojoyo : Jurnal Pendidikan dan Pembelajaran Anak Usia Dini, Volume 7, Nomor 2, Oktober 2020 hal 23-32, ISSN : 2528-3553 (online), ISSN: 2407-4454 (print)

mereka. Ada yang bertugas di meja kasir, penanggungjawab es krim dan cake, pelayan, dan chef yang membuat kue.

Ada pengunjung kafe yang berasal dari kelas lain. Pelayan segera mempersilahkan tamu untuk duduk, dan memperlihatkan daftar menu. Tamu itu memilih beberapa macam makanan dari berbagai macam gambar makanan yang tertempel di buku menu. Dan memintanya kepada pelayan. Pelayan itu menulis dnega sungguh-sungguh apa yang dipesan oleh tamu. Setalh itu, banyak sekali tamu yang datang ke kafe tersebut.

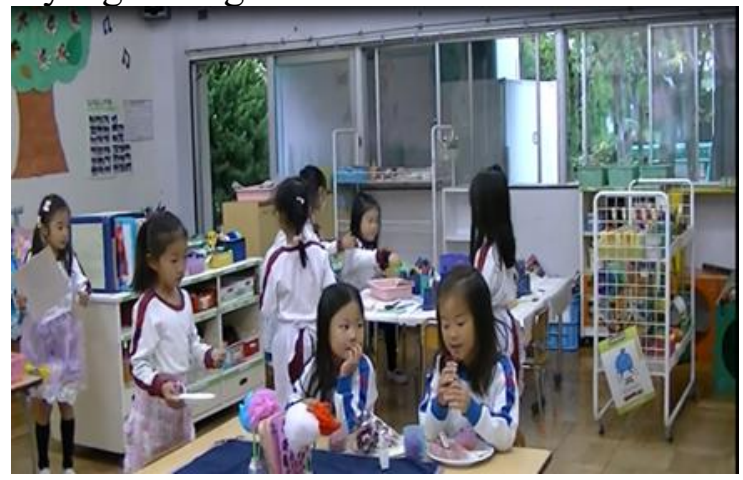

Gambar 4. Bermain Drama Pelayan

\section{Kafe}

Di dalam kafe anak-anak yang berperan sebagai pegawai kafe berkonsentrasi dengan pekerjaannya. Para tamu pun terlihat menikmati es krim yang sedang mereka makan. Di meja sebelah, chef juga sangat serius membuat cake dan es krim. Pelayan mengeluarkan pesanan makanan dan es krim untuk tamu. Anak-anak benar-benar tenggelam dalam permainan mereka.

\section{Bermain Sepeda Roda Satu}

Di tempat yang jauh dari kelas, di halaman TK ada beberapa orang anak yang sedang berlatih sepeda roda satu. Bu Guru membantu berlatih anak yang belum bisa menaiki sepeda roda satu.

\section{Sesi Makan Siang}

Pada pukul 11.20 JST, dengan aba-aba dari Bu Guru, jam bermain pun selesai. Anak-anak yang bermain di luar membereskan alat-alat permainan yang dipakai dan meletakkannya kembali ke tempatnya. Alat-alat permainan yang dipakai di bak pasir, dibilas dulu dengan air sebelum dikembalikan ketempatnya. Di dalam kelas, permainan pelayan kafe juga sudah selesai. Semua peralatan yang dipakai, seperti es krim, cake, kasir, dll, dirapikan agar bisa digunakan lagi di waktu yang lain.

Anak-anak memilih tempat dan meletakkan kursi nya sendiri di samping teman yang ia sukai, agar bisa mengobrol dengan temannya sambil makan. Saat memilih tempat duduk, ada satu anak yang tidak bisa masuk ke grup mana pun dan merasa kecewa. Anak lain menyadari hal itu dan mencoba menghiburnya. Saat itu ada anak yang memakai sweater biru mengajak anak yang kecewa tadi ke tempat yang lain. Ibu Guru yang melihat itu, mengajak anakanak membicarakan masalah ini bersamasama, akhirnya anak yang kecewa tadi pun mau duduk di tempat yang lain. Sesi bincangbincang berlanjut.

Selanjutnya mereka membicarakan tentang hal-hal yang ingin ditanyakan terkait dengan permainan yang mereka lakukan tadi pagi. Awalnya anak yang bermain permainan kafe merasa bingung dengan beberapa hal, seperti pesanan yang tidak datang-datang dan makanan yang belum selesai di makan, tapi sudah dibereskan oleh pelayan. Mereka lalu membahasnya bersama-sama. Setelah itu $\mathrm{Bu}$ Guru mengajak anak-anak untuk mencari halhal baik dan membicarakannya bersama-sama. Terutama ide-ide bagaimana caranya agar permainan yang sedang dimainkan bisa menjadi semakin menyenangkan.

Jam 11.40 JST kegiatan bincangbincang bersama selesai. Empat orang anak yang bertugas menyiapkan kegiatan makan siang maju ke depan kelas. Anak-anak itu mengucapakan kata-kata pendahuluan yang biasanya diucapkan sebelum kegiatan makan siang, lalu meletakkan mangkuk, gelas dan sumpit ke meja masing-masing kelompok. Setelah itu, ke empat anak itu duduk di kursinya masing-masing dan mulai makan. 
Jurnal PG-PAUD Trunojoyo : Jurnal Pendidikan dan Pembelajaran Anak Usia Dini, Volume 7, Nomor 2, Oktober 2020 hal 23-32, ISSN : 2528-3553 (online), ISSN: 2407-4454 (print)

Sesi siang dimulai setelah makan, tepatnya dari jam 12.30 JST. Setelah makan anak-anak kembali melakukan permainan bebas yang tetap dimonitor dan sesekali dipandu oleh guru. Permainan yang sempat diobservasi adalah membuat terowongan dari pasir di area bermain pasir di halaman.

\section{Membuat Terowongan dan Sungai di Gunung Pasir}

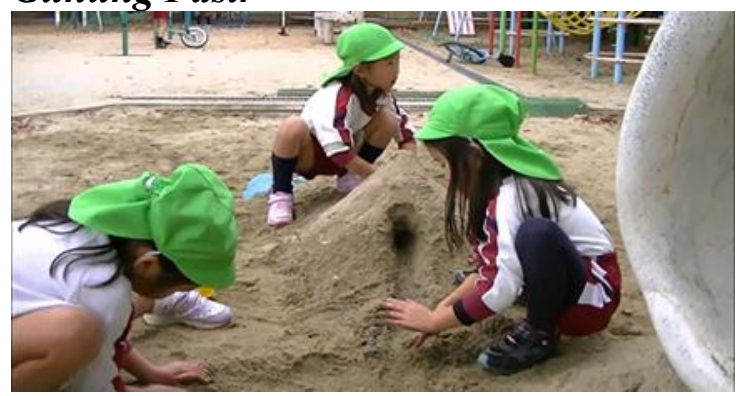

Gambar 5. Membuat Terowongan \& Sungai

Setelah makan siang, anak-anak kembali bermain. Di bak pasir anak-anak membuat gunung pasir dengan cara menabur pasir di atas gundukan tanah, lalu ditekan-tekan hingga mengeras. Awalnya mereka membuat dua gunung. Tapi ketika anak yang membuat gunung lebih besar mulai melubangi gunung tersebut, yang lain mulai memfokuskan perhatiannya kepada gunung tersebut. Sambil membuat lubang di gunung tersebut, terdengar lagu "ayo membuat lorong di gunung" yang dinyanyikan oleh salah seorang dari mereka. Lalu, lambat laun lubang yang dibuat semakin dalam, sampai akhirnya tembus ke sisi lain dari gunung tersebut. Lalu mereka mulai membuat jalan di luar gunung tersebut. Kemudian ada beberapa anak yang datang karena tertarik juga dnegan permainan itu. Terakhir, ada anak yang mengambil air, dan menuangkan air ke lubang di gunung itu, lalu terciptalah sungai kecil.

Di tempat lainnya juga terlihat permainan seperti yang dimainkan oleh anak-anak pada pagi hari. Latihan sepeda satu roda, dodge ball, perosotan, dll, di semua tempat terlihat anak-anak yang bermain dengan dan larut dalam permainan mereka.

\section{Persiapan Pulang}

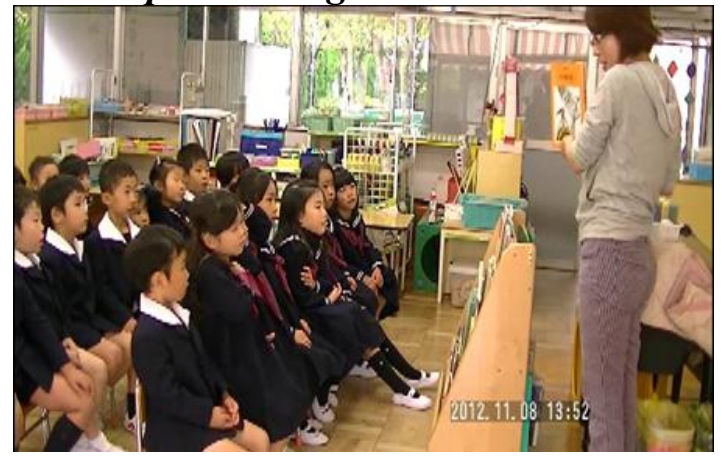

Gambar 6. Persiapan Pulang

Pukul 13.30 JST barang-barang yang dibawa anak-anak dari rumah dimasukkan ke dalam tas. Anak-anak membuka baju oleh raga di dalam kelas dan memasukkannya ke dalam tas khusus. Setelah berganti baju, mereka menarik kursi ke tengah ruangan dan duduk. Lalu sambil menunggu sampai semua temannya selesai berganti baju mereka membaca buku. Setelah semua anak selesai berganti baju, ibu guru memainkan piano, dan anak-anak menyanyikan lagu sambil melihat teks lagu yang tertulis di dinding di depan kelas. Setelah bernyanyi, ibu guru membacakan sebuah buku, dan anak-anak menyimak cerita $\mathrm{Bu}$ Guru dengan serius. Setelah membaca buku, ibu Guru sekali lagi meminta anak-anak untuk mencari hal-hal baik yang sudah terjadi hari ini. Sekarang giliran petugas piket hari ini yang diminta untuk bercerita. Setelah selesai berbicara, anak-anak mengembalikan kursinya ke tempat semula, mengambil tas dan keluar dari kelas. Sambil mengantar anak keluar kelas, Ibu Guru secara singkat menanyakan kepada setiap anak tentang apa yang mereka lakukan hari ini sambil memperbaiki kerah baju atau menepuk-nepuk bahu mereka dan mengucapkan selamat jalan dan sampai jumpa lagi. 
Jurnal PG-PAUD Trunojoyo : Jurnal Pendidikan dan Pembelajaran Anak Usia Dini, Volume 7, Nomor 2, Oktober 2020 hal 23-32, ISSN : 2528-3553 (online), ISSN: 2407-4454 (print)

\section{PEMBAHASAN}

Metode utama yang digunakan dalam pendidikan di TK Laboraturium Aichi Jepang adalah bermain bebas. Di sini, para siswa dibebaskan untuk memilih sendiri permainan yang diinginkannya, tanpa ada arahan dari guru. Karena permainan di pilih sendiri oleh siswa, dengan mudah mereka bisa tenggelam dalam permainan dan berinteraksi dengan teman lainnya, baik yang seusia dengannya atau dengan adik kelasnya, serta dengan benda-benda yang ada di sekitarnya. Guru di sini berperan mengobservasi apa yang dilakukan oleh setiap siswa, membantu mereka saat mereka kesulitan dalam melakukan suatu permainan, atau membantu mereka agar bisa tenggelam dalam permainan. Hal ini sesuai dengan prinsip neurosains nomor 1 , yaitu pertumbuhan otak yang cepat pada anak usia di bawah 6 tahun, mendorong mereka untuk mengeksplorasi, menemukan, bermain, dan membuat hubungan alami antara diri, orang lain, dan dunia sekitarnya. Selain itu juga sesuai dengan prinsip nomor 8 , yaitu pembelajaran anak usia dini menggunakan esensi bermain.

Karena metode yang digunakan adalah bermain bebas, anak-anak belajar untuk membuat aturan dalam permainannya sendiri, tidak ada tekanan sehingga proses pembelajaran jadi menyenangkan. Hal ini sejalan dengan prinsip nomor 2 yaitu Kondisi yang menyenangkan, aman, dan nyaman akan mengaktifkan bagian cerebral korteks (otak berpikir) sehingga dapat mengoptimalkan proses belajar dan meningkatkan kepercayaan diri anak, serta nomor 4 Proses pembelajaran dilakukan dengan cara yang menyenangkan agar otak siswa memroduksi neurotransmitter dopamine yang membuat siswa menyukai aktivitas di TK dan terlibat aktif dalam proses pembelajaran.

Meskipun metode pendidikannya bermain bebas, namun arahan Ibu Guru dalam proses belajar terlihat dalam kegiatan saat berbincang-bincang yang isinya membahas tentang apa yang dilakukan dalam permainan, terutama masalah-masalah yang mereka temukan selama bermain. Ibu Guru melakukan dialog dengan anak-anak, mengarahkan siswa untuk mencari pemecahan masalah tersebut. Dari aktivitas ini, Ibu Guru terlihat melatih siswa untuk mengaktifkan otak depan (korteks prefrontal) siswa. Dalam peristiwa di mana ada siswa yang tidak bisa duduk berdekatan dengan teman yang disukainya, Bu Guru juga mengajak seluruh kelas untuk berdiskusi, bagaimana cara memecahkan masalah tersebut dengan baik. Hal ini sesuai dengan prinsip neurosains nomor 3, yaitu di usia 3-6 tahun merupakan masa di mana prefrontal korteks berkembang dengan sangat pesat. Prefrontal korteks ini memiliki fungsi eksekutif, sehingga latihanlatihan pemusatan perhatian, mengontrol tindakan seperti melawan kebiasaan, godaan atau gangguan, mengingat informasi dan membuat perencanaan menjadi aktivitas yang penting untuk dilakukan.

Prinsip nomor 7 juga terlihat dalam seluruh hasil observasi, yaitu otak anak-anak perlu dihadapkan dalam kehidupan nyata, langsung, dan pengalaman belajar yang bermakna, yang terkait dengan kesamaan dan dihadapkan pada beberapa bentuk pemecahan masalah. Metode bermain bebas membuat anak belajar langsung dari masalah-masalah yang timbul saat permainan. Masalah dengan teman, masalah saat kesulitan memutar badan di tiang gymnastik, masalah aturan permainan yang tidak sesuai (dalam permainan pelayan café yang membereskan meja padahal hidangan belum selesai dimakan) dan hal-hal lain yang sangat bermakna bagi dunia anak-anak.

Prinsip nomor 5, aktivitas belajar ditargetkan sampai pada keterampilan, sehingga bisa dicapai oleh semua siswa. Hal ini terlihat bukan saja dalam menguasai permainan saat sesi bermain bebas, namun juga siswa TK B di sana sudah mampu 
Jurnal PG-PAUD Trunojoyo : Jurnal Pendidikan dan Pembelajaran Anak Usia Dini, Volume 7, Nomor 2, Oktober 2020 hal 23-32, ISSN : 2528-3553 (online), ISSN: 2407-4454 (print)

melakukan hal-hal yang berkaitan dengan dirinya sendiri secara mandiri. Misalnya, mengganti baju, membereskan mainan, menunggu teman-temannya selesai berganti baju dalam persiapan pulang, melakukan tugas harian sebagai petugas makan siang dan lain-lain.

Apa yang dilakukan Ibu Guru di kelas ini sangat sesuai dengan prinsip nomor 6 , yaitu setiap hari tugas guru adalah menyapa dengan sambutan hangat, mendorong mereka untuk berkembang sebagai individu, memberikan tantangan pribadi, melibatkan mereka dalam pengembangan lingkungan kelas, dan mendukung perbedaan individu. Ibu Guru tidak hanya diam melihat anak-anak bermain, namun berkeliling memperhatikan siswanya, mendorong mereka untuk menguasai permainan, memberikan pujian, memberi semangat, mengarahkan siswa untuk bisa mengatasi masalah yang mereka hadapi serta menunjukkan sikap yang hangat, terutama ditunjukkan saat mengantarkan anak-anak keluar dari kelas.

Meskipun di sebagian besar waktu yang dalam aktivitas di TK adalah bermain, namun ada saat-saat semua siswa berada di kelas, dan mengikuti arahan dari guru, yaitu saat menjelang makan siang sampai selesai makan, dan saat menjelang pulang. Sebelum makan siang, anak-anak duduk dengan rapi dan mengikuti aktivitas diskusi yang diarahkan oleh guru. Lalu membereskan tempat bekal makanan yang sudah selesai dimakan isinya, membereskan meja dan kursi sesuai dengan posisi semula, serta siap untuk kembali bermain dengan permainan yang mereka inginkan. Pada pukul 13.30 anak-anak kembali masuk ke dalam kelas, berganti baju dengan tertib, menunggu teman-teman yang belum selesai mengganti baju dengan membaca buku, mendengarkan guru membacakan cerita dan bernyanyi, setelah itu pulang. Dari lima setengah jam waktu yang dilalui anak-anak di sekolah, sekitar satu setengah jam dipakai untuk kegiatan terstruktur yaitu berupa diskusi, makan siang dan aktivitas sebelum pulang. Semuanya itu sesuai dengan isi dan tujuan di TK Jepang yaitu anak mampu melakukan sendiri aktivitas-aktivitas sehari-hari yang penting, seperti membersihkan apa yang ada di sekitarnya, makan, aktivitas ke toilet, dan lain-lain. Bagaimana proses pendidikan di TK tersebut sehingga mampu membuat anak-anak mau mengikuti aktivitas yang diarahkan oleh guru dengan disiplin yang tinggi, padahal mereka sedang asyik bermain dengan permainan yang mereka sukai, hal ini memerlukan penelitian yang lebih mendalam.

\section{SIMPULAN DAN SARAN}

Dari hasil analisa di atas terlihat dengan jelas bahwa metode bermain bebas, yang menjadi aktivitas di TK Laboraturium Aichi Jepang sangat sesuai dengan prinsip-prinsip neurosains. Di sini guru tidak berperan sebagai "pengajar", yang mengajarkan berbagai macam hal kepada siswa, seperti yang banyak dilakukan di TK Indonesia, namun peran guru adalah sebagai fasilitator yang mendrong siswa untuk terlibat penuh dalam permainan yang ia pilih sendiri. Selain itu, tugas guru adalah membuat siswa menyadari apa pelajaran yang bisa dipetik melalui permainan yang ia lakukan. Guru juga mendorong mereka untuk tidak mudah menyerah, memberikan pujian dan penguatan di saat siswa menghadapi masalah.

Kekurangan dalam penelitian ini adalah, observasi hanya dilakukan dalam waktu satu hari, sehingga peneliti tidak bisa menggali informasi yang lebih mendalam tentang proses pembelajaran, sehingga bisa mengetahui bagaimana siswa TK B di TK laboraturium Aichi University of Education bisa melakukan tugas-tugas mereka dengan disiplin yang tinggi. Bila observasi bisa dilakukan dalam jangka waktu yang lebih lama ditambah dengan metode wawancara yang dilakukan kepada guru TK, mungkin bisa lebih banyak informasi yang bisa digali 
Jurnal PG-PAUD Trunojoyo : Jurnal Pendidikan dan Pembelajaran Anak Usia Dini, Volume 7, Nomor 2, Oktober 2020 hal 23-32, ISSN : 2528-3553 (online), ISSN: 2407-4454 (print)

terkait dengan aktivitas pendidikan di TK tersebut.

\section{DAFTAR PUSTAKA}

Ariyanti, Tatik (2016). Pentingnya Pendidikan Anak Usia Dini Bagi Tumbuh Kembang Anak. JURNAL DINAMIKA PENDIDIKAN DASAR VOLUME 8, NO 1, Maret $2016: 50-$ 5.

Hayashi, Akiko (2011). The Japanese Handsoff Approach to Curriculum Guidelines for Early Childhood Education as a For of Cultural Practice. Asia-Pacivic Journal of Research. Vol. 5, No. 2, pp. 107-123.

Hunter, Joshua at al., (2017). Adult Perspectives on Structured vs. Unstructured Play in Early Childhood Environmental Education. International Journal of Early Childhood Environmental Education Copyright (C) North American Association for Environmental Education ISSN: 2331-0464 (online).

INBRIEF SERIES. The Science of Early Childhood.

www.developingchild.harvard.edu

Insiyah, Ma'fiyatun (2019). Bermain Bebas untuk Optimalisasi Perkembangan Kognitif Anak Usia Dini di TK Omah Dolanan YWKA Yogyakarta. Indonesian Journal of Islamic Early Childhood Education P-ISSN: 25412418; E-ISSN: 2541-2434 Ijiece, Vol. 4, No. 1, June 2019 (19-18).

Istiana, Yuyun (2014). Konsep-konsep Dasar Anak Usia Dini. Didaktika, Vol. 20 No. 2 Februari 2014

Nur, Hifizah (2013). Curriculum Development Research of Indonesian Kindergarten Based on the Perspective of "Playing with Nature" Unit from Living Environmental Studies in Japan. Thesis of Aichi University of Education.
Ministry of Education, Culture, Sports, Science and Technology (2008). Course of study for Kindergarten. http://www.mext.go.jp/component/eng $\underline{\text { lish/ icsFiles/afieldfile/2011/04/07/1 }}$ $303 \overline{755}$ 002.pdf

Golstein, Jeffery (2012). Play in Chidren's Development, Health and Well-being. TIE PDF.

Gowrie SA research summary (2015). Brain Development. www.ipsplibrary.net.au

Guo, Karen (2017). Values, Risks, and the Shaping of Kindergarten Rules in Japan. Asia-Pacific Journal of Research. Vol.11, No.2, pp.45-46

Hermidan, M.J., dkk (2014). Cognitive neuroscience, developmental psychology, and education: Interdisciplinary development of an intervention for low socioeconomic status kindergarten children. ScienceDirect. Elsevier.

Wang, Sam \& Aamodt, Sandra (2012). Play, Stress, and the Learning Brain. NCBI Journal Cerebrum. 2012 Sep-Oct; 2012: 12. Published online 2012 Sep 24.

Qudsyi, Hazhira (2010). Optimalisasi Pendidikan Anak Usia Dini Melalui Pembelajaran Yang Berbasis Perkembangan Otak. Buletin Psikologi Fakultas Psikologi Universitas Gajah Mada. Volume 18, No. 2

Rushton, Stephen dkk (2009). Neuroscience, Play and Early Childhood Education: Connections, Implications and Assessment. Springer Science+Business Media, LLC 2009

Rusthon, Stephen (2011). Neuroscience, Early Childhood Education and Play: We are Doing it Right!. Springer Science+Business Media, LLC 2011.

Santrock, J. W., (2011). Life-Span Development. Edisi Bahasa Indonesia. Erlangga. 